\title{
1. Domestic Transformation in the Global Context
}

Ross Garnaut, Ligang Song, Cai Fang and Lauren Johnston

\section{Introduction}

China is experiencing its most persistent substantial slowdown in economic growth since the early years of reform. Annual growth has sagged from an average of 10 per cent per annum in the first decade of the century to just more than 7 per cent in 2014. As we discussed in the China Updates for 2006 and 2013, some slowing was inevitable and welcome to authorities. The slowdown anticipated in 2006 and 2013 is auspicious - driven by structural factors and necessary to sustain economic growth. The question now is whether we are observing the slowdown that is anticipated, and necessary to establish a foundation for a drive towards the productivity frontiers of the world economy, or a slowdown that has other causes.

There are two candidates for something else. One is a cyclical slump from withdrawal of the extraordinary fiscal and monetary stimulus to maintain growth after the global financial crisis (GFC). This prospect is rendered more severe by associated weaknesses in the financial system revealed by the withdrawal of stimulus, and from continuing weakness in the developed world's economy and therefore in demand for Chinese exports. The second is a less auspicious structural slowdown, deriving not from productive structural change within a new model of economic growth, but from the accumulation of uncorrected structural weaknesses from the old model of growth that become more and more damaging as China moves closer to the world's productivity frontiers.

The main focus of this year's China Update is on the detail of structural change within the new model of growth. Many chapters take a close look at one or other area of the economy in which change is required to sustain growth. The authors generally record nascent progress and grounds for hope, but rarely evidence that China is well on its way to the structural change that would see its emergence in the next decade as a high-income modern economy. 
There has nonetheless been productive structural change in two areas. One is the structural change driven by the labour market transformation associated with the shift from abundance to scarcity of unskilled labour. The other is the substantial and continuing change in the relationship between growth and pressure on the natural environment that is being driven by policy.

The past two growth slowdowns in China occurred in response to the Asian Financial Crisis (1998-99) and the GFC (2008-09). Now, as then, there have been suggestions that the deceleration of the actual economy is greater than has been recorded in the official statistics. It was common during the two previous slowdowns to point to much slower growth in partial indicators, such as electricity demand or freight volumes, as evidence that the actual economy had slowed more than the official statistical economy. Premier Li Keqiang, in an earlier provincial role, once suggested that the partial indicators were more reliable than the statistical aggregates. Significance has therefore been attached to the recent absolute declines in electricity use (1.1 per cent in April 2015 compared with the previous April) and rail freight volume (down 9 per cent in the first quarter of 2015 compared with the corresponding period of 2014). Huang (2015) has suggested that the real growth in output could have been something like 5 per cent rather than the official statistical 7 per cent in the year to early 2015 .

Analysis at the time of the two preceding growth slowdowns suggested some basis for downgrading the official statistical aggregates at times of slower growth. These related to difficulties of calculating price deflators in conditions of weak demand and tendencies to deflation. There could be some overestimation in the recent data. Structural change, especially related to use of energy, has, however, been large enough for us to expect fundamental shifts in the old relationships between the favourite partial indicators and actual growth. The 5.6 per cent decline in energy intensity of economic activity, to which the decline in electricity consumption is related, is only a small extension of the rate of decline in 2014. This in turn is only moderately above the 4 per cent per annum decline envisaged in the Twelfth Five-Year Plan. In these circumstances, a small decline in electricity consumption, while unlikely to continue for long, is not hopelessly inconsistent with a 7 per cent increase in total output. Similarly, coal accounts for a high proportion of rail freight in China, so the large movement away from coal as a source of energy associated with the new environmental objectives - leading to coal use in the first quarter of 2015 being well below the corresponding quarter of the previous year-accounts for much of the slump in freight volumes.

The slowdown could be a bit larger than measured by official data, and in any case is substantial. More importantly, the weakness so far of structural change associated with the new model of growth means that some powerful headwinds 
will be felt more strongly in future than now. In the best of circumstances, a period of lower growth has still to be experienced before a foundation has been laid for China's drive towards high-income status.

Chapters 2, 3 and 9 discuss how some of the slowing of growth has been driven by demographic and labour market change, and how much of the remainder has cyclical or inauspicious structural causes. The inauspicious structural causes are mostly related to imbalances that emerged in the fiscal and monetary response to the GFC.

Our 2006 Update highlighted the consequences of the demographic and labour market changes summed up as 'the turning period in economic growth'. Unskilled labour in the countryside ceased to be abundant and available in large amounts at fairly steady wages from the middle of the first decade of the new century, soon causing wages to grow more rapidly than output. Other changes were driven by the turning period in the labour market: increased wages led to the reversal of the longstanding increase in the investment share of output, and the slow beginnings of a rise in the consumption share. The rise in the wages share of income led to reversal of the longstanding tendency for inequality in income distribution to increase over time. This could be expected to incrementally reduce the investment share of domestic expenditure, so that slower growth in the capital stock would join the decline in the labour force to place downward pressure on the rate of growth (Garnaut and Song 2006). How far that decline went would depend on policies to make the economy more flexible and better able to allocate resources to their most productive uses - that is, productivityraising economic reform.

The 2013 volume introduced the idea that China was working within a new model of economic growth, driven by policy change to promote new objectives as well as by the economic pressures from the labour market (Garnaut et al. 2013). The new objectives include more equitable income distribution; higher household consumption, especially of services and especially in rural areas; acceptance of a moderately lower rate of growth; and a reduction in the pressure applied by each increment in economic activity on the natural environment. The new model of economic growth was judged to be necessary to sustain growth so that China could join the minority of countries so far that, having attained upper middle-income status, as China has now done, go on to join the high-income countries. A further doubling of output per person after 2010 was required for China to achieve this outcome. Reform of many institutions and policies was necessary for this to be possible. These new priorities and model of growth were embodied in the reform decisions of the Third Plenary meeting of the Chinese Communist Party's Eighteenth Central Committee late in 2013. 
The view that recent declines in economic growth reflect stronger influence from cyclical than structural policies is supported in Chapters 2 and 3. The slowdown so far has clear footprints from the turning point in the labour market. However, beyond important changes in the relationship between growth and pressure on the environment, there is so far little evident influence of new policies designed to bring economic outcomes more closely in line with community objectives and to lay the foundations for transition to an advanced modern economy.

The continuation of the deceleration in growth that has been evident for several years into the first quarter of 2015 is more than a 'regression to the mean' (Pritchett and Summers 2014). It reflects the overlapping of three tendencies: the changing of gears associated with the new model of growth, which is necessary to keep growth going; the painful adjustment associated with the removal of external and internal imbalances from the old growth model; and the absorption of the excesses hanging over from the extraordinary fiscal and monetary stimulus that powered China through the aftermath of the GFC. The third, cyclical set of influences includes high debt levels, especially at the local government level, and overcapacity in many industrial sectors, both of which increase risks in China's financial sector.

What we called 'China's new model of economic growth' has since been described by the government and others in China as the 'new normal'. New normal growth requires extensive institutional reform, including changes in the hukou system to remove artificial impediments to efficient use of rural labour in urban areas; in the financial system, to allow capital to be allocated to its most productive use; in land management, to ensure that the opportunity cost of scarce land is reflected in its use and that peasants are adequately compensated for transfer of land to more economically valuable uses; in increased investment and better use of resources in education, especially in rural areas, to increase opportunities for all citizens in an expanding modern economy; in removal of barriers to innovation and effective use of intellectual capital by strengthening property rights and facilitating the exchange of knowledge; and in removal or economically efficient regulation of state monopolies to raise efficiency in goods and services markets. Reforms in these areas can increase productivity, generating a 'reform dividend' partially to compensate for the loss of the 'demographic dividend' and for lower contributions to growth from increase in the capital stock (Lu and Cai 2014). Stronger impetus to growth from productivity-raising reform could be augmented in the longer term by relaxation of population policy, although the actual effect of changing the one-child policy at this stage of Chinese development is uncertain.

China's drive towards high-income status needs mutually reinforcing contributions from reform in many areas. Productivity has to be raised in all activities, and resources must be encouraged to move from less to more 
productive uses. The structural change from less to more productive uses of resources has many dimensions: from less to more profitable firms; from lowvalue to high-value goods and services; from rural to urban locations; and from less to more productive regions. As Kuznets (1961) noted more than half a century ago, resources need to continue to shift from low-productivity areas such as agriculture to high-productivity areas such as industry-just as they did under the old model of growth, within which more than 250 million rural workers migrated into cities. China has to accept 'creative destruction' wherever it increases economic value, and needs to reform institutions and policies to allow creative destruction to do its work.

There are several risks to China right now continuing to shift resources from relatively low to high-productivity activities (Cai 2015). First, there may not be enough new migrant workers moving from rural areas to towns to replace migrant workers returning to rural areas from now on. This risk arises from demographic change as well as from institutional barriers that prevent migrant workers from settling permanently in cities. The annual growth rate of migrant workers flowing into cities has fallen from 4 per cent in the period 2005-10 to about 1.3 per cent in 2014. The continuation of this trend would undermine an important source of productivity growth, since rural-urban migration is estimated to have contributed about half of China's total factor productivity (TFP) improvement over considerable periods in the reform era.

Second, the rate of urban growth is bound to fall, and unless there is timely downward adjustment in rates of urban infrastructure investment, capital will be wasted in overcapacity.

Third, upgrading of the industrial structure associated with the new model of growth requires increasingly educated and experienced labour. Current rural education standards and incentives for migrants to accumulate and apply skills in urban employment may not make this more sophisticated labour available to expanding urban industries. In these circumstances, rural migrant workers are particularly vulnerable to structural unemployment when they are not covered by urban insurance for unemployment and other social security provisions. At the same time, they cannot easily be re-employed in the agricultural sector because of changes in their own preferences and in technology applied in increasingly productive agriculture. The resulting structural unemployment could be a potential source of social instability.

Fourth, China's rebalancing towards a rising share of services and falling share of secondary industry could lower the overall rate of productivity improvement. Secondary industry in general has higher labour productivity than tertiary industry. For example, average labour productivity (defined as the ratio of industrial value added over total employment) in China was 1.45 for 
secondary industry and 1.22 for tertiary industry in 2013. However, the impact on productivity depends on whether secondary industry is progressing towards producing higher value-added products and the service industries, including research and development (R\&D), design, marketing and post-sales services, which support them. In that case, overall productivity could be enhanced by the development of the service sector. However, industrial restructuring that mainly involves shifting workers from low-end manufacturing production to low-end services could have a negative impact on productivity growth.

These risks highlight the importance of reform to direct resources continually into more productive areas. An important requirement for continuous structural economic upgrading is creative destruction (Schumpeter 1934). This allows inefficient or unproductive activities to depart from the market, so saving resources for use in more efficient, innovative and productive activities. For creative destruction to succeed, governments, especially local governments, should desist from seeking to save industries making losses and losing comparative advantage. Instead, they should nurture market competition and minimise the social costs of structural transition.

The arrival of the Lewis turning period has weakened the competitiveness of China's traditional labour-intensive industries. China's revealed comparative advantage (RCA) index for labour-intensive goods (the ratio of China's labourintensive exports to total exports, relative to the same ratio for the world as a whole) fell from 4.4 in 2003 to 3.4 in 2013. The downward trend continues.

China's integration into the global economy has forced a worldwide reallocation of economic activities. China's massive labour-intensive industries have started moving from the coastal regions to inland regions and at the same time to other countries, especially in South-East and South Asia but also in Africa. This 'flying geese' or 'flying dragon' pattern is potentially positive for global as well as Chinese development, alongside the upgrading of China's industrial production towards high value-added manufacturing products.

China's State Council unveiled a national plan recently, which is called 'Made in China 2025'. It is a 10-year action plan designed to transform China from a low-end to a high-end manufacturing giant. It covers 10 sectors (People's Daily online, 22 May 2015): new information technology; numerical control tools and robotics; aerospace equipment; ocean engineering equipment and hightech ships; railway equipment; energy-saving and new energy equipment and vehicles; power equipment; new materials; biological medicine and medical devices; and agricultural machinery. This new strategy, coupled with the international strategy of 'one belt and one road', supported by the formation of the Asian Infrastructure Investment Bank (AIIB), reflects a comprehensive 
approach to a new growth model. If successfully implemented, China's exports of manufactured goods at a higher level will dominate a changing global division of labour, supporting productive structural change in China itself.

Comprehensive success requires a favourable international environment. This is increasingly problematic. There is increasing concern about the sustainability of the export-oriented growth model in China and other East Asian economies, against a weakening of the multilateral trading system and the proliferation of preferential arrangements. These are likely soon to be joined by the formation of a large preferential trading area that excludes the large Asian countries: China, India and Indonesia. Optimists see this as being a stepping stone to comprehensive free trade in the Asia-Pacific. Realists see risks in the immense gains from free multilateral trade that have underpinned Asia-Pacific development in the past half-century.

Outside Asia, the capacity and willingness of developed countries to accept the structural change required for absorption of large quantities of exports from newly competitive suppliers of high-value products are diminished by slow economic growth and the increase in protectionist instincts that this inspires. Continued deepening of international integration would help all countries to meet the economic challenges they face; a reversal of the globalisation process would make life harder for everyone. China's circumstances provide an opportunity for gains from global leadership (Garnaut and Song 2006). China's leadership role in championing a new wave of globalisation is present in some areas but not in others. The establishment of the AIIB is a good sign: new mechanisms to support capital outflow alongside increased export of capital goods from the higher-income countries to support infrastructure for development in lowerincome countries are needed now to restore momentum for economic growth in developed and developing countries alike. China would do global development as well as its own development a good turn by demonstrating similar leadership in unilateral trade liberalisation, which is the most likely way out of the increasingly dense maze of preferential trading arrangements in the Asia-Pacific.

The rebalancing from exports to consumption as a source of growth within China's new economic model also reduces adjustment pressures in the rest of the world. This creates a different set of opportunities for export expansion in the rest of the world than the old model of growth, which favoured exports of minerals and energy commodities, with all of the challenges of resource-led growth in the exporting countries (Collier 2007; Sachs and Warner 1997).

The next five years of transition are crucial to the success of the new model of growth. Success would deliver the targeted doubling of per capita income by 2020 from the 2010 level. That would lift China across the income threshold 
of a developed country. There is a good chance but no certainty of success. Reforms must be deepened to lift productivity and to make growth more inclusive and environmentally sustainable.

This year's China Update offers both domestic insight and global context into this challenging new phase of China's economic transformation. The following chapters shine a light on policy reform, institutional change and economic performance in a number of specialised areas of the Chinese economy. Many are important in themselves, and all provide insights into the complex process of transition through which China is seeking to make its way from middle income into the ranks of the developed countries.

A complex set of institutional changes covering political rather than narrowly economic transition will help to determine the fate of China's advance into the ranks of developed economies. Inductive logic would draw from the experience of the countries that are now developed: the conclusion that all high-income countries have (more or less) competitive political systems in which the votes of citizens can change the political party of government. It would draw the conclusion that all high-income countries provide freedom of exchange of information among citizens and between citizens and other people that extends well beyond common practice in China.

It is in the nature of inductive logic that a new set of observations can transform our knowledge. Nassim Taleb (2007) in his classic book about financial irrationality notes that the swan was synonymous with whiteness until Willem de Vlamingh sailed through the heads of what is now Fremantle Harbour in 1696. He then observed the black swans that were of sufficient note for him to give the name Swan to the river that opened before him. If China achieves advanced-economy status without fundamental political change, a majority of people living in high-income countries will live under authoritarian and not democratic governments. The world will see another black swan.

Inductive logic raises some questions about whether China can reach the status of a high-income country without large changes in political institutions. This book does not cover these important matters. They have been discussed by economists elsewhere (Dollar 2015; Huang 2015), and will be part of the agenda of the China Update on future occasions. 


\section{Structure of the book}

Chapters 2, 3 and 9 take a closer look at the macroeconomic story, focusing on the influences on the growth slowdown and the policies proposed to remedy it.

In Chapter 2, Ross Garnaut examines structural change within China's economic growth. Change is being driven by pressures endogenous to economic development, and by new objectives and policy. The former include rising wages and changes in the relative priorities of increases in income and the quality of health, longevity and the natural environment that come with higher incomes. The new model of growth that accepts the growing scarcity and value of labour, and the higher priority of equity in income distribution and environmental amenity are necessary to sustain growth so that China can enter the ranks of high-income countries. The transition to a new model of growth, and, if that transition is successful, to an advanced economy, could be smooth or rough. Smooth adjustment would see investment falling and consumption rising by a commensurate amount - and productivity growth rising so as partially to balance the declining contribution to growth of increase in the amount of labour and capital deployed in the economy.

There are some positive signs suggesting progress in applying the new model of growth. Real wages are rising at a faster rate than gross domestic product (GDP). Inequality as measured by the Gini coefficient is falling after many years of moving in the opposite direction. Trends in the share of investment and household consumption of GDP are in the right direction, but almost imperceptible in size. There is so far only a weak footprint of the new growth model in the economic indicators.

The slowdown in growth is larger than the limited progress in implementing the new model of growth would lead us to expect. That suggests large cyclical and unproductive structural causes of the slowdown in growth since 2011. Growth in TFP is falling markedly - although the experience of other countries suggests that the causes may not all be specific to China. This suggests little progress in the qualitative reforms that are at the heart of the new model of growth-and of the decisions of the Third Plenum in 2013.

One area in which the new model does have bite is in changes in the relationship between economic growth and pressure on the environment. Use of lowemissions energy is rising rapidly, and the early twenty-first-century explosion in the use of coal and other fossil fuels has come to an abrupt end. Changes in the intensity and composition of energy use are being driven by domestic concerns for health and longevity as well as international concerns about climate change and desires to limit insecurity derived from dependence on imported fossil fuels. Implementation of the more narrowly economic dimensions of the new 
model of growth - for example, through the decline in the investment share of expenditure - would accelerate progress on environmental objectives, and can be expected in future with success in China's transition to a developed country.

In Chapter 9, Rod Tyers explains how the GFC forced China to confront the economic imbalances that are the legacy of three decades of rapid growth. For one-quarter of a century into the reform era, until about 2005, China's abundant and cheap labour kept labour costs low and increased consumer choice and welfare in high-income economies. The gains within China and in its trading partners favoured the owners of capital, and in some industries had adverse consequences for workers. What will be the consequences of China's new growth model for high-income economies?

Tyers explores that question using a global macroeconomic model that allows for rebalancing of national asset portfolios and endogenous representation of unconventional monetary policy. Modelling results suggest that high-income countries could see modest increases in inflation, but the associated adverse fall in the terms of trade could help to restore employment levels. Those results also suggest that successful Chinese transition towards higher consumption and lower savings should reverse the impact on high-income economies of China's old model of growth.

In Chapter 3, Guonan Ma makes the case for monetary easing in China - a policy shift that began in late 2014. The international context of Chinese monetary easing is the post-financial crisis monetary easing by the central banks of Japan, the United States, the European Union and the United Kingdom. One consequence of the developed countries' monetary policies was an unintended tightening of Chinese policy. Ma argues that this is a cause of Chinese growth in recent years being slower than would be optimal. This carries risks and increases the difficulties of reform.

Ma's chapter makes a compelling case for monetary reform around three perspectives: the Taylor rule for the domestic monetary expansion; China's tight monetary conditions in the face of unconventional monetary policy operations by the central banks of the big four economies; and the relationship between Chinese and fiscal policies in determining the exchange rate. Ma sees monetary easing as being important for short-term stability as well as to provide a congenial context for economic reform to the new model of growth.

In Chapter 4, Meiyan Wang and Cai Fang explore one area of untapped consumer potential: China's vast pool of migrant workers. The hukou residency registration system - which limits cross-provincial and urban-rural cross-worker access to social security, health and education-forces higher levels of precautionary savings than are considered acceptable by local peers. 
Meiyan Wang and Cai Fang use data from the China Urban Labour Survey to analyse consumption patterns among migrant and local households in six cities in China. Finding the difference between migrant and local consumption to be statistically significant, the authors extrapolate the consumption potential were migrant workers to enjoy the same benefits and rights as locals. The chapter concludes that reform that empowers China's migrant workers to consume at the level of their local peers would support China's new economic strategy by unlocking massive untapped consumer potential.

In Chapter 5, Ran Li, Xiang Li, Wen Lei and Yiping Huang debate the options for accelerating reform and opening of China's banking sector. Since shortly after China joined the World Trade Organization (WTO), foreign banks have dramatically expanded their absolute presence in China, with their assets growing at an average annual rate of 20 per cent. Contrary to earlier fears, they have failed to crowd out Chinese banks and have encountered many difficulties in operating in China. Their shares of total banking assets have fallen. Chinese banks seem to have benefited from the learning and competition spillovers generated by foreign banks in China without losing business to them.

The authors seek to quantify the impact of foreign banks on competition in China's banking sector. Exploring a subset of China's banking sector- the nonstate banking sector at the provincial level — the authors find that foreign banks are associated with positive competition effects in China. Net interest margins and non-interest expenses as a share of total earnings are both lower where foreign banks are active.

Reform is delivering efficiency advantages without obviously damaging established Chinese interests.

In Chapter 6, Qing King Guo, Chi Keung Marco Lau, Kunwang Li and Ligang Song explore whether the efficiency of coal, gasoline and gas markets is increasing in China. They do this by focusing on changes in price differentials across regions. Recent advances in the collection of spot-price data allow the 'law of one price' to be tested. The chapter also assesses progress in the integration of markets across China's regions. The massive increase in demand for energy in the past few decades makes this an interesting area for testing changes in the efficiency of markets.

There is little support for the law of one price in China in the analysis of energy price changes across the regions and years that were studied. An average convergence rate of 40 per cent is calculated. Diesel prices converged most, with 60 per cent of the diesel sample suggesting convergence in price across regions over time. Electricity prices remained most divergent. There were also 
indications of the extent of convergence varying within category groupings, especially with respect to coal products. The results were attributed to price protection, geographic barriers and other government policies.

In Chapter 7, Xunpeng Shi and Hari Malamakkavu Padinjare Variam explore the case of liberalisation of China's gas market, which began a decade ago. Those reforms include the creation of gas trading hubs and gas benchmark pricing - intended to improve the infrastructure and liquidity of the gas market. Since China is now a net gas importer, the world's third-largest consumer of gas and intends to increase the role of gas in its energy mix, understanding gas market liberalisation in China is important to the global gas industry. The first part of the chapter provides a qualitative summary of these trends and changes, and of the powerful role of China's three large state-owned gas companies.

The chapter then applies an empirical model to examine the impact of China's gas liberalisation on trade flows and gas prices. An Asian gas trade model utilises a dataset covering 2006 and projections forward to 2035. China would lose if it was alone among East Asia's major gas importers in deregulating its gas market. A unique study of China-Australia gas ties finds that Australia is likely to do best under the continuation of a long-term contract system. For China, the optimal scenario is one of a mixed-economy model: a combination of long-term contracts and spot-price purchasing.

In Chapter 8, Stephen Wilson, Yufeng Yang and Jane Kuang outline the complex challenges facing China's electricity producers. After suffering persistent blackouts in the 1980s, by the first decade of the new century, the electricity sector instead had a 'golden decade', characterised by rising growth in demand and generation capacity. China now has the world's largest hydropower sector, the world's largest and most rapid nuclear plant construction program and the largest installed capacity for wind and solar power. Managing this sector against demand for power, environmental concerns, industrial competitiveness and, finally, equality and livelihood concerns necessitates continuous reforms.

The main focus of the chapter is on models of price deregulation and their relevance to China. The authors extract lessons from the experiences of major electricity-consuming countries for China's own electricity reforms. Early this century, China's electricity reforms were most influenced by the UK example of separation of power generation and the grid, parallel with establishing an electricity supervision council. Benchmarking against different international experience continues. The period 2020-50 is cited as expected to produce major milestones in energy, the economy and the environment for China, and thus future trends in China's electricity market could be future trends in the global electricity market. Most of the data end in 2010, so the insights from the chapter are of historical relevance. 
In Chapter 10, Liqing Zhang and Qin Gou lay out alternative approaches for China's prospective opening of the capital account. An extreme choice is to open with a 'big bang'. This could be efficient in terms of capital allocation and risk diversification but is subject to large financial volatility risks. The choice of opening model is complicated by the need for synchronisation with decisions on reform of the banking sector, liberalisation of finance and floating the national currency. Consequences of reform are affected by the international business cycle.

Zhang and Gou review the theoretical and empirical literature, which explores both the mode and the sequencing of capital account opening. They add a random effects probit model to that literature, and utilise a sample of 50 countries to explore how different scenarios of reform sequencing and opening mode affect the likelihood of a financial crisis in China. Under no scenario does the risk exceed 15 per cent. The risk is lowest in the case of China incrementally opening its capital account in tandem with undertaking broader financial reforms.

In Chapter 11, Will Nixon, Eden Hatzvi and Michelle Wright unravel and explain China's cautious and policy-driven approach to internationalising the renminbi (RMB). They describe the prevailing view that RMB internationalisation can only move in tandem with broader capital account liberalisation. The latter, however, is being served by the gradual rise of offshore RMB trading, for it is increasing the international flow of China's currency. This experience provides insight for Chinese central bankers seeking to understand how greater openness to currency trade might work.

Nixon, Hatzvi and Wright explain the motivations for China proceeding with these sensitive monetary reforms, and the important role of the Bank of China and the Bank of Hong Kong to that process. By early 2015 the local branches of Chinese banks in 15 cities outside mainland China had been granted official RMB clearing bank status. Some 28 central banks have signed bilateral currency swap agreements with China, while 40 invest a proportion of their foreign-exchange reserves in renminbi. The experience of the central banks and investors utilising the increasing number of RMB-denominated stock investor programs is increasing understanding of influences on the RMB exchange rate.

In Chapter 12, Kevin Zhang ponders differences in industrial goods production and industrial competitiveness, in a comparative study of China's changing industrial strength. A UN Industrial Development Organization (UNIDO) dataset of industrial competitiveness indicators provides the basis for assessing China's relative total and per capita international strength in production and exports of manufacturing value added over time. 
Zhang finds that China has come a long way in terms of capacity and intensity. China's industrial intensity now exceeds that of some industrialised economies, but it has a long way to go in quality. Similarly, since much of the progress in industrial capacity and intensity was driven by foreign-invested firms and processing trade, China has a long way to go to reach its goal of more indigenous industrial strength.

In Chapter 13, Mei (Lisa) Wang, Zhen Qi and Jijing Zhang draw our attention to the massive rise in China's outbound investment activity. Of the four phases of China's outbound investment development, the first two cover the years 19802000, and were of modest dimension. Since 2002, however, official statistics suggest that China's outbound investment has increased 45 times, reaching US\$116 billion in 2014. Since the GFC, average annual outbound foreign direct investment (FDI) has reached US\$74 billion.

Unlike China's slowing 'new normal' domestic growth rate, the new normal for outbound investment carries annual growth projections in the range of 20 per cent to 2020. Growth could be volatile. The scale of China's investment is daunting. The unique and complicated institutional structure of China's stateowned enterprises present new and challenging territory for investor recipient countries.

Chunlai Chen in Chapter 14 uses a provincial-level panel dataset and employs the fixed-effects model to investigate empirically the inter-regional spillovers from coastal FDI on inland provinces. The study finds that FDI in the northern and eastern coastal provinces (which are moderately engaged in processing trade) has positive spillovers on the economic growth of inland provinces, while FDI in southern coastal provinces (those heavily engaged in processing trade) has had a negative effect on the economic growth of inland provinces. The explanation for this could be that processing trade has no industrial linkages with inland regions and cannot generate backward and forward knowledge spillovers to firms in inland provinces. China should redesign processing trade policies to focus on increasing local sourcing and enhancing industrial linkages through economic structural reform and industrial upgrading.

In Chapter 15, Fan He and Xiaoming Pan shed light on the emerging complexities of fragmenting world trade negotiations. Ostensibly in direct response to the decade-long stalemate in the multilateral Doha negotiations of the WTO, selective country groupings have now initiated more exclusive mega-regional negotiations. The fragmenting of global trade with the rise of trade-in-parts makes old trade rules less relevant. China has joined the race to update international trade rules. The chapter reveals an absence of clarity in the goals of the race. Some of the proposed new arrangements, especially the US-led Trans-Pacific Partnership (TPP), appear designed to exclude China. 
In Chapter 16, Lauren Johnston writes of the evolution of China-Africa economic ties over time. Explaining the interdependent trends in flows of trade, investment and aid, Johnston notes that while today China is Africa's largest trading partner, China's investment plans offer most insight into the direction of these ties.

As a result of China's slower growth within its new model, there has been a dramatic decline in the price of many energy and metals commodities. For commodities exporters in Africa, this means a painful readjustment. In contrast, for net commodities importers, China's new model of growth is good news for the terms of trade. The chapter outlines how China plans to greatly increase investment in infrastructure, labour-intensive manufacturing and steelmaking in Africa. The precedents for sustainable growth across time and countries suggest that the prospects for growth of China's outbound investment to facilitate industrialisation in Africa are especially important in coastal economies experiencing an improvement in terms of trade, such as Kenya and Tanzania.

In Chapter 17, Gao Xiang and Huiqin Jiang explore China's new foreign investment legal regime, which took effect in September 2013. Changes to that regime centre on the China (Shanghai) Pilot Free Trade Zone (SPFTZ), and are part of China's efforts to modernise the financial sector and to move closer to the industrial frontier.

Innovations within the new investment law regime include the adoption of preestablishment national treatment, and a negative list. The latter has attracted significant attention, and includes gambling industries and a list of national products such as types of tea. The reporting and filing system for foreign investors has also been simplified. The new systems adopted in the SPFTZ for foreign investment differ greatly from those applied previously in China, demonstrating the Chinese Government's efforts to integrate into the international economic market and adopt generally accepted international rules.

\section{References}

Cai, F. (2015), Looking at sources of economic growth under the 'new normal' from an international perspective, Unpublished, Chinese Academy of Social Sciences, Beijing.

Collier, P. (2007), The bottom billion: Why the poorest countries are failing and what can be done about it, Oxford: Oxford University Press. 
Dollar, D. (2015), Institutional quality and growth trends, PAFTAD37 Conference, Institute of Southeast Asian Studies, Singapore, June.

Garnaut, R. and Song, L. (2006), Truncated globalisation: The fate of the Asia Pacific economies?, in Soesastro, H. and Findlay, C. (eds), Reshaping the Asia Pacific economic order, London: Routledge, pp. 46-81.

Garnaut, R., Cai, F. and Song, L. (2013), China's new strategy for long-term growth and development, in Garnaut, R., Cai, F. and Song, L. (eds), China: A new model for growth and development, Canberra: ANU E Press, pp. 1-16.

Huang, Y. (2015), Can China rise to high income, PAFTAD37 Conference, Institute of Southeast Asian Studies, Singapore, June.

Kuznets, S. (1961), Economic growth and the contribution of agriculture: Notes on measurement, International Journal of Agrarian Affairs, 3(April): 56-75.

Lu, Y. and Cai, F. (2014), China's shift from the demographic dividend to the reform dividend, in Song, L., Garnaut, R. and Cai, F. (eds), Deepening reform for China's long-term growth and development, Canberra: ANU Press, pp. 27-50.

Pritchett, L. and Summers, L.H. (2014), Asiaphoria meets regression to the mean, NBER Working Paper No. 20573, Cambridge, Mass.: National Bureau of Economic Research.

Sachs, J.D. and Warner, A.M. (1997), Natural resource abundance and economic growth, Cambridge, Mass.: Harvard University Press.

Schumpeter, J.A. (1934), The theory of economic development, Cambridge, Mass.: Harvard University Press.

Taleb, N. (2007), The black swan: The impact of the highly improbable, New York: Random House. 
This text is taken from China's Domestic Transformation in a Global Context, edited by Ligang Song, Ross Garnaut, Cai Fang \& Lauren Johnston, published 2015 by ANU Press, The Australian National University, Canberra, Australia. 